\title{
Willingness to Join Community-Based Health Insurance and Its Associated Factors among Households in West Gojjam Zone, North Mecha Woreda ,Amhara region, Ethiopia
}

Getaneh Bizuayehu Demeke ( $\nabla$ getanehuog@gmail.com )

University of Gondar

Research

Keywords: Community, health insurance, willingness to join, West Gojjam, Ethiopia

Posted Date: October 11th, 2021

DOl: https://doi.org/10.21203/rs.3.rs-952468/v1

License: (c) (1) This work is licensed under a Creative Commons Attribution 4.0 International License. Read Full License 


\section{Abstract \\ Background}

Community-based health insurance schemes are becoming increasingly recognized as a potential strategy to achieve universal health coverage in developing countries. Ethiopia is a low income country with more of health spending out of pocket payment by households. Health insurance is also expected to provide financial protection because it reduces the financial risk associated with falling ill. Therefore; financial risk in the absence of health insurance is equal to the out-of-pocket expenditures because of illness.

\section{Method}

Cross-sectional community based study design was conducted by using a pretested structured questionnaire. Multi-stage cluster, simple random and systematic sampling techniques was used to select 296 households as study units which were allocated to the kebeles proportionately. The sampled households were selected using simple random sampling technique. Bivariate and multivariate logistic regression was used for analysis of variables and $95 \%$ confidence level and $P$ value $<0.05$ was used to measure strength of association.

\section{Results}

A total of 296 sampled study participants, 285 participated in this study with a response rate of $96.3 \%$.From this, $(90.9 \%)$ were willing to join and $(89.8 \%)$ of them were willingness to pay $\mathrm{CBHI}$. the benefits of join the scheme were as follows, (86.8\%) were reduce OOP expenditure, $(8.3 \%)$ of them improve health status, $(2.3 \%)$ were reduce the risk of severity and $(2.6 \%)$ foster productivity.

\section{Conclusions}

This study showed that the proportion of willingness to join $\mathrm{CBHI}$ was higher than the findings of others study in the country and it is encouraging for planned strategy to expanding the scheme throughout the country. The main challenges utilization of health services in government health institutions were absence of available medicine, poor service delivery, lack of enough laboratory, health professional's lack of good behavior and shortage of ambulance services. To alleviate such problem the government should be encourage access to health services.

\section{Background}

Community based financing is defined as 'a generic expression used to cover a large variety of health financing arrangements like micro insurance, community health funds, mutual health organizations, rural 
health insurance and community involvement in user-fee management' [1].Community-Based Health Insurance is a type of insurance means informal sectors through contributing some amount of money, and the schemes are not-for-profit type of health insurance that has been used by poor people to protect themselves against the high costs of seeking medical care and treatment for illness [2]. It covers a wide variety of health insurance arrangements with vast gradients in terms of ownership, management, membership, and service as well as financial coverage in distinctive settings and designed for different population groups [1].

Community-based social dynamics and collective risk sharing, solidarity, participatory decision-making and administration, non-profitability and voluntary membership are characteristics of community-based health insurance schemes. The schemes provide free health care services, included benefit packages, for individual or household members who enroll by paying premium required [3].

Globally, about 44 million households faced catastrophic health expenditure while about 25 million households are impoverished because of direct health care payments. Over $90 \%$ of healthcare financial difficulties and their consequences have been occurring in Sub-Saharan African countries, where resources are limited [4].In the majority of African countries including Ethiopia, more than $40 \%$ of their total health expenses were constituted by out-of-pocket payment and this resulted in scarcity of finances for health [5].

Universal health coverage monitoring report in 2017 showed that many people lack essential health service and people are pushed into poverty spending too much budget. It showed that in the entire worlds, more than 7.3 billion people do not receive all essential health service they needs. Over 800 million people spend at least $10 \%$ of their household budget to pay for health care and 100 million people are pushed to extreme poverty due to their health care expenditure [6].Low enrollment in $\mathrm{CBHI}$ remains a challenge in many African countries. Out of the total 900 million catchment population, only 2 million people are participating in the $\mathrm{CBHI}$ scheme, which accounts for only $0.2 \%$ of the catchment population [5].

CBHI schemes have been operating in sub-Saharan African since the 1990s [9].However, enrollment and retention have been a problem [7, 8]. In 2006, only 2 million out of an estimated 900 million people were enrolled in a $\mathrm{CBHI}$ scheme in Africa [9]. A recent systematic review of the literature on $\mathrm{CBHI}$ coverage in low-and middle-income countries shows that supply and demand side factors impact enrollment [10]. Mebratie et al., in their study of drop-out rates in Ethiopia, highlighted three additional factors that contributed to $\mathrm{CBHI}$ renewal: the cost of premiums, health status and understanding of health insurance [8].

The government of Ethiopia is working to narrow the existing wide gap between community demand for health care and financial constraints in the health sector by implementing the $\mathrm{CBHI}$ scheme in rural areas [11].Currently, $\mathrm{CBHI}$ scheme is being implemented over 161 districts and recent evaluation shows improvements in health service utilization among districts implementing $\mathrm{CBHI}$ scheme [12]. Health-care financing in Ethiopia has been characterized by low government spending, strong reliance on out-of- 
pocket expenditure, inefficient and inequitable utilization of resources, and poorly harmonized and unpredictable donor funding over the years [13].

The benefits packages of $\mathrm{CBHI}$ in Ethiopia include all family health services and curative care that are part of the essential health package in Ethiopia when the scheme is scaled up to full implementation. Curative services include inpatient, outpatient services and acute illnesses [14]. Therefore, the objectives of this study was assessment of willingness to join community based health insurance and factors associated with households in North Mecha Woreda, West Gojjam Zone, Amhara region, Ethiopia.

\section{Methods}

\section{Study setting, design and methods}

The study was conducted in North Mecha Woreda, West Gojjam Zone, and Amhara region. Amhara region is the second most populous region in Ethiopia next to Oromia region. From the total population of Amhara [49.9\%] were male and $51.1 \%$ of them female population. The majority of the population were rural residence (80.6\%). The community based cross-sectional study design was conducted. The study was used quantitative research methods as a tool for data collection. Structured questionnaire was employed to collect data from the study households heads.

\section{Data types and sources}

Both primary and secondary data type was used in this study. The primary data source was obtained from structured questionnaire. While, the secondary data source also obtained through published and unpublished documents, like books, journal articles and annual research reports of various institutions that are relevant to this study included to obtain secondary data.

\section{Source and study population}

All households in Wets Gojjam administrative Zone were considered as source population and all household heads in the randomly selected Kebels from Woreda were the study populations.

\section{Sampling techniques}

You know that various researchers use different sampling techniques and procedures based on, the interest of the investigator, the nature of study and the number of study subjects. For this study, probability sampling technique was used to select the study area and study subjects. The researcher was used a multi-stage cluster sampling techniques to select the study area ,subjects, and the proportionate allocation would be used to determine the sample of each selected kebeles from study the site. In the first stage, from the total of thirty six kebeles of the Woreda, ten kebeles were selected using simple random sampling techniques. In the second stage, by using systematic sampling, the list of household heads were obtained from family folder or community health information system at health center. Finally, the study participants were selected using simple random sampling. 


\section{Sample size determination}

The sample size was determined using single population proportion formula, with the assumptions of $5 \%$ margin of error and $95 \% \mathrm{Cl} ; \mathrm{Za} / 2=$ Critical value $=1.96$, taking $\mathrm{P}=77.8 \%=0.778$ was done in Bugna district, Northeast, Ethiopia and $10 \%$ non-response rate .

$$
\begin{aligned}
& \text { Where, } \mathrm{n}=\text { required sample size } n=\frac{\left(\frac{z \alpha}{2}\right)^{2} p(1-p)}{d^{2}}[15] \\
& =\frac{\left(\frac{1.96}{2}\right)^{2} 0.778(1-0.778)}{0.05^{2}}=265+\left(265^{*} 0.1\right)=\mathbf{2 9 6}
\end{aligned}
$$

\section{Data collection}

Data were collected using a structured questionnaire and the questionnaire was developed based on available information obtained from various literature. The questionnaire was prepared first in English and next translated into Amharic local language for data collection process. Six trained data collectors and two supervisors were involved in the data collection process. Supervisors followed the data collectors and provided any necessary correction on the spot.

\section{Data quality control}

To control data quality accurately, the intensive training was provided one day about the aims of the study, procedures and data collection techniques. Prior to the study $5 \%$ pretest structured questionnaire was carried out on household heads outside the study area to check the reliability of the questionnaire. Some questionnaire was adjusted based on pretest findings. Next to this, the data collectors goes to normal data collection process. The collected data was reviewed, checked for completeness by supervisor's manually each day before enter to SPSS software. After this, data entering, editing, cleaning and analysis was done by using SPSS software version 22 .

\section{Data analysis}

The collected data was analyzed using binary and multivariate logistic regressions to determine the effect of various factors on the outcome variable. The results were presented in the form of tables and text using frequencies and summary statistics such as standard deviation, mean, and percentage to describe the study population in relation to relevant variables. The degree of association between dependent and independent variables was assessed using odds ratio with $95 \%$ confidence interval and $p$ value $<0.05$ declared statistical significance.

\section{Results}




\section{Demographic and socio-economic characteristics of respondents}

A total of 285 study participants responded for the interviews, making the response rate $96.3 \%$. All in all, $(90.9 \%)$ of the study participant households were willing to join the community-based health insurance scheme. Among study participants, $(88.4 \%)$ and (11.6\%) were male and female respectively. The age of the respondents has been classified with 4 age categories. The results show that, $(10.9 \%)$ of the respondents were in age category of 18-28, While(16.8\%) them were from 50 and above 50 years and (34.1\%)were from $40-49$. The significant number of the respondent's $(38.2 \% \%)$ was in the age category of 29-39. This implies that, the majority of the respondents were concentrated in the age category of adult and productive age. Regarding to place of the residence, majority of the respondents (81.1\%) were rural and the rest (18.9\%) were urban dweller. Concerning to religious affiliation of the study participants, $(86.3 \%)$ and $(13.7 \%)$ they were Orthodox and others.

It can be understood that, the majority study participants from marital status category was married (89\%). Concerning the educational level (44.2\%) of the respondents were illiterate, $(29.8 \%)$ them were read and write educational status, while (26.8\%) of them were primary school and above. As shows in Table 1 , the occupational status of the respondents $(60.7 \%)$ were engaged farming and $(7.7 \%)$ were house wife. The $5.3 \%$ of the respondents were government employee, while $(12.3 \%)$ were working as a daily laborer and $(14 \%)$ of them were merchants. The study result shows that $(74.4 \%),(18.9 \%)$ and $(6.7 \%)$ of the respondents have an average monthly income from 300-2000, 2001-4000 and 4001-9000 ETB within households respectively. 
Table 1

Demographic and socio-economic characteristics of study participants in North Mecha Woreda, West Gojjam Zone, Amhara region Ethiopia

\begin{tabular}{|c|c|c|c|}
\hline \multicolumn{2}{|l|}{ Variables } & \multirow{2}{*}{$\begin{array}{l}\text { Frequency }(\mathrm{N}) \\
252\end{array}$} & \multirow{2}{*}{$\begin{array}{l}\text { Percentage (\%) } \\
88.4\end{array}$} \\
\hline Sex & Male & & \\
\hline & Female & 33 & 11.6 \\
\hline \multirow[t]{4}{*}{ Age } & $18-28$ & 31 & 10.9 \\
\hline & 29-39 & 109 & 38.2 \\
\hline & $40-49$ & 97 & 34.1 \\
\hline & 50 and above 50 & 48 & 16.8 \\
\hline \multirow[t]{2}{*}{ Place of residence } & Rural & 231 & 81.1 \\
\hline & Urban & 54 & 18.9 \\
\hline \multirow[t]{2}{*}{ Religion } & Orthodox & 246 & 86.3 \\
\hline & Others & 39 & 13.7 \\
\hline \multirow[t]{4}{*}{ Marital status } & Single & 15 & 5.3 \\
\hline & Married & 254 & 89 \\
\hline & Widower/Widow & 10 & 3.5 \\
\hline & Divorced & 6 & 3.1 \\
\hline \multirow[t]{3}{*}{ Educational status of $\mathrm{HH}$} & Illiterate & 126 & 44.2 \\
\hline & Read and write & 85 & 29.8 \\
\hline & Primary school \& above & 74 & 268 \\
\hline \multirow[t]{5}{*}{ Occupational status of $\mathrm{HH}$} & Farming & 173 & 60.7 \\
\hline & House wife & 22 & 7.7 \\
\hline & Government employee & 15 & 5.3 \\
\hline & Laborer & 35 & 12.3 \\
\hline & Merchants & 40 & 14 \\
\hline \multirow[t]{3}{*}{ Monthly average income of family } & $300-2000$ & 212 & 74.4 \\
\hline & $2001-4000$ & 54 & 18.9 \\
\hline & $4001-9000$ & 19 & 6.7 \\
\hline
\end{tabular}

Filed survey, 2020/21 


\begin{tabular}{|llll|}
\hline Variables & & Frequency $(\mathrm{N})$ & Percentage (\%) \\
\hline Household size & $1-3$ & 136 & 47.7 \\
\cline { 2 - 4 } & $4-6$ & 118 & 41.4 \\
\cline { 2 - 4 } & 7\&above & 31 & 10.9 \\
\hline Filed survey, 2020/21 & & & \\
\hline
\end{tabular}

\section{The characteristics of respondents by the levels of WTJ, health status and health service utilization}

Among study participants, $90.9 \%$ of households had joined a CBHI scheme. The majority of participants, $(35.8 \%)$ of them were join before three years ago, while, (15.4\%), (25.3\%), and( $23.5 \%)$ of them were join ,before one year, two years and four years ago respectively. From 285 total study participates (93.3\%) were reported that join in $\mathrm{CBH}$ have advantages, while, the benefits were as follows, $(86.8 \%)$ were reduce OOP expenditure, $(8.3 \%)$ of them improve health status, $(2.3 \%)$ were reduce the risk of severity and $(2.6 \%)$ foster productivity.

Among participants who had WTJ, (89.8\%) were also willing to pay for this proposed health insurance scheme. With regard to $\mathrm{CBHI}$ premium, $(70.2 \%)$ of respondents reported that paying the proposed health insurance cost was affordable. Majority of the respondents (89.2\%) were renew family member ID timely and paid the renewal ID cost, $(100 \%)$ were covered by self-sponsor. Among those respondents the amount of expenditure cost to register and renewed ID, (70.2\%), (15.4\%), and (14.4\%) were found the interval from, 240-350, 351-450, and 451-1000 ETB with decreasing order respectively.

As Table 2, indicated (80\%) of respondents family members had encountered an illness in the past one year. Of which, (80\%) got a medical treatment from different health facility. From those respondents, (17.5\%), (46.5\%) and (36\%) of them were from public health center, private health center and government hospital respectively. And (86.4\%), respondents that it took $>60$ minutes to reach the health facility. Among 285 sampled respondents, (43.2\%) were $\mathrm{CBHI}$ package fulfil the needs of household treatment and majority of the respondents $(72.6 \%)$ said that $\mathrm{CBHI}$ facility provided good services. It can be understood that, $(45.6 \%)$ of the respondents rated their perceived quality of health care service in the district as low, while the overall CBHI service level was poor(66.7). The main challenges utilization of health services in government health institution, (34.2\%), (32.7\%), (26.3\%),(4.2\%) and (2.6\%) were absence of available medicine, poor service delivery, lack of enough laboratory equipment, health professionals not have good behavior and shortage of ambulance services respectively. 
Table 2

The characteristics of respondents by the levels of WTJ, health status and service utilization in North Mecha Woreda, West Gojjam Zone, Amhara region, Ethiopia

\begin{tabular}{|c|c|c|c|}
\hline Variables & Responses & $\begin{array}{l}\text { Frequency } \\
(\mathrm{N})\end{array}$ & $\begin{array}{l}\text { Percentage } \\
(\%)\end{array}$ \\
\hline \multirow[t]{2}{*}{ Willingness to join $\mathrm{CBHI}$} & Yes & 259 & 90.9 \\
\hline & No & 26 & 9.1 \\
\hline \multirow[t]{4}{*}{ When you join $\mathrm{CBHI}$} & Before one year ago & 44 & 15.4 \\
\hline & Before two year ago & 72 & 25.3 \\
\hline & Before three year ago & 102 & 35.8 \\
\hline & Before four ago & 67 & 23.5 \\
\hline \multirow[t]{2}{*}{ Join CBHI have advantage } & Yes & 266 & 93.3 \\
\hline & No & 19 & 6.7 \\
\hline \multirow[t]{4}{*}{ Benefits of join in $\mathrm{CBHI}$} & Reduce OOP expenditure & 231 & 86.8 \\
\hline & Improve health & 22 & 8.3 \\
\hline & Reduce the risk of Severity & 6 & 2.3 \\
\hline & Foster productivity & 7 & 2.6 \\
\hline \multirow[t]{2}{*}{ Willingness to pay CBHI } & Yes & 256 & 89.8 \\
\hline & No & 29 & 10.2 \\
\hline \multirow[t]{2}{*}{$\mathrm{CBHI}$ premium is affordable } & Yes & 200 & 70.2 \\
\hline & No & 85 & 29.8 \\
\hline \multirow[t]{2}{*}{ Renew your \& family member ID timely } & Yes & 256 & 89.2 \\
\hline & No & 29 & 10.2 \\
\hline Paid registration\& renewal ID cost & Self-sponsor & 285 & 100 \\
\hline \multirow{3}{*}{$\begin{array}{l}\text { Amount of expenditure cost to register } \\
\text { and renewed ID }\end{array}$} & $240-350$ & 200 & 70.2 \\
\hline & $351-450$ & 44 & 15.4 \\
\hline & $451-1000$ & 41 & 14.4 \\
\hline \multirow{2}{*}{$\begin{array}{l}\text { Had family members experience of } \\
\text { illness in the past one year }\end{array}$} & Yes & 228 & 80 \\
\hline & No & 57 & 20 \\
\hline Got a medical treatment & Yes & 228 & 80 \\
\hline Filed survey, 2020/21 & & & \\
\hline
\end{tabular}




\begin{tabular}{|c|c|c|c|}
\hline Variables & Responses & $\begin{array}{l}\text { Frequency } \\
(\mathrm{N})\end{array}$ & $\begin{array}{l}\text { Percentage } \\
\text { (\%) }\end{array}$ \\
\hline & No & 57 & 20 \\
\hline \multirow[t]{3}{*}{ Place of treatment } & Public health center & 40 & 17.5 \\
\hline & Private health center & 106 & 46.5 \\
\hline & Government hospital & 82 & 36 \\
\hline \multirow{2}{*}{$\begin{array}{l}\text { Distance home to health facility in } \\
\text { minutes }\end{array}$} & $<60$ minutes & 31 & 13.6 \\
\hline & $>60$ minutes & 197 & 86.4 \\
\hline \multirow[t]{6}{*}{ Time waited to see medical doctor } & $<30$ minutes & 7 & 3.1 \\
\hline & $30-60$ minutes & 43 & 18.9 \\
\hline & 1- 3 hours & 78 & 34.2 \\
\hline & 3-6 hours & 59 & 25.9 \\
\hline & 6 hours \&more & 36 & 15.8 \\
\hline & More than one day & 5 & 2.2 \\
\hline \multirow{2}{*}{$\begin{array}{l}\mathrm{CBHI} \text { package fulfil the needs of } \mathrm{HH} \\
\text { treatment }\end{array}$} & Yes & 123 & 43.2 \\
\hline & No & 162 & 56.8 \\
\hline \multirow{2}{*}{$\begin{array}{l}\mathrm{CBHI} \text { health facilities provided a good } \\
\text { service }\end{array}$} & Yes & 207 & 72.6 \\
\hline & No & 78 & 27.4 \\
\hline \multirow{5}{*}{$\begin{array}{l}\text { Perceived quality of health care service } \\
\text { in the district }\end{array}$} & Very low & 5 & 1.8 \\
\hline & Low & 130 & 45.6 \\
\hline & Medium & 100 & 35.1 \\
\hline & High & 39 & 13.7 \\
\hline & Very high & 11 & 3.9 \\
\hline \multirow[t]{2}{*}{ Overall CBHI service level } & Poor & 190 & 66.7 \\
\hline & Good & 95 & 33.3 \\
\hline \multirow{2}{*}{$\begin{array}{l}\text { Challenges to use services in } \\
\text { government health institution }\end{array}$} & Absence of available medicine & 65 & 34.2 \\
\hline & $\begin{array}{l}\text { Lack of enough laboratory } \\
\text { equipment }\end{array}$ & 50 & 26.3 \\
\hline
\end{tabular}

Filed survey, 2020/21 


\begin{tabular}{|lllc|}
\hline Variables & Responses & $\begin{array}{l}\text { Frequency } \\
\text { (N) }\end{array}$ & $\begin{array}{l}\text { Percentage } \\
\text { (\%) }\end{array}$ \\
\hline & $\begin{array}{l}\text { Shortage of ambulance } \\
\text { service }\end{array}$ & 5 & 2.6 \\
\cline { 2 - 4 } & $\begin{array}{l}\text { Poor service delivery } \\
\text { Health professionals do not } \\
\text { have good behavior }\end{array}$ & 8 & 32.7 \\
\hline Filed survey, 2020/21 & & & 4.2 \\
\hline
\end{tabular}

\section{Factors Associated With Willingness To Join Cbhi}

Bivariate and multivariate analysis of logistic regression model were carried out to identify factors associated with willingness to join $\mathrm{CBHI}$ scheme. Variables with p-value of less than 0.2 in bivariate analysis were entered to multivariate analysis. The study revealed that household heads whose residence in urban area ,occupation working as merchant compared to farmer, occupation employed in merchant compared government employee, willingness to pay, join in $\mathrm{CBHI}$ scheme have advantage, $\mathrm{CBHI}$ packages fulfil the needs of $\mathrm{HH}$ treatment and $\mathrm{CBHI}$ health facilities provided good services, were significantly associated with join in $\mathrm{CBHI}$ at $\mathrm{p}$-value $<0.05$. 
Table 3

Bivariate and multivariate analysis of factors associated with willingness to join community-based health insurance among households in North Mecha Woreda, West Gojjam Zone, Amhara region, Ethiopia

\begin{tabular}{|c|c|c|c|c|c|}
\hline \multirow[t]{3}{*}{ Variables } & \multirow{2}{*}{\multicolumn{2}{|c|}{$\begin{array}{l}\text { Willingness } \\
\text { to } \\
\text { Join CBHI }\end{array}$}} & \multirow{2}{*}{\multicolumn{2}{|c|}{ Odds Ratio(OR) }} & \multirow[b]{3}{*}{ AOR(95\%Cl) } \\
\hline & & & & & \\
\hline & Yes & No & B & $\operatorname{coR}(95 \% \mathrm{Cl})$ & \\
\hline \multicolumn{6}{|c|}{ Place of residence } \\
\hline Rural & 209 & 22 & $-0.999(0.395)$ & $\begin{array}{l}0.368(0.169-0.802) \\
0.012\end{array}$ & $\begin{array}{l}1.484(2.343- \\
6.427) 0.025\end{array}$ \\
\hline Urban & 42 & 12 & & 1 & 1 \\
\hline \multicolumn{6}{|l|}{ Religion } \\
\hline Orthodox & 221 & 25 & $-0.975(0.485)$ & $\begin{array}{l}0.377(0.161-0.884) \\
0.025\end{array}$ & $\begin{array}{l}1.624(0.334-7.900) \\
0.548\end{array}$ \\
\hline Others & 30 & 9 & & 1 & 1 \\
\hline \multicolumn{6}{|c|}{ Educational level of $\mathrm{HH}$} \\
\hline Illiterate & 119 & 7 & $-1.545(-1.084)$ & $\begin{array}{l}0.213(0.083-0.547) \\
0.001\end{array}$ & $\begin{array}{l}0.338(0.061-1.875) \\
0.215\end{array}$ \\
\hline Read \& write & 74 & 11 & $\begin{array}{l}-0.618 \\
(-0.629)\end{array}$ & $\begin{array}{l}0.539(0.232-1.250) \\
0.150\end{array}$ & $\begin{array}{l}0.533(0.115-2.466) \\
0.421\end{array}$ \\
\hline $\begin{array}{l}\text { Primary } \\
\text { \&above }\end{array}$ & 58 & 16 & & 1 & 1 \\
\hline \multicolumn{6}{|c|}{ Occupational status of $\mathrm{HH}$} \\
\hline Farming & 165 & 8 & $-2.296(-2.321)$ & $\begin{array}{l}0.101(0.038-0.266) \\
0.000\end{array}$ & $\begin{array}{l}0.098(0.027-0.363) \\
0.001\end{array}$ \\
\hline House wife & 19 & 3 & $-1.115(-1.209)$ & $\begin{array}{l}0.328(0.082-1.311) \\
0.115\end{array}$ & $\begin{array}{l}0.298(0.060-1.491) \\
0.141\end{array}$ \\
\hline $\begin{array}{l}\text { Gov't } \\
\text { employee }\end{array}$ & 14 & 1 & $-1.908(-3.000)$ & $\begin{array}{l}0.148(0.018-1.253) \\
0.080\end{array}$ & $\begin{array}{l}0.050(004-0.639) \\
0.021\end{array}$ \\
\hline Laborer & 26 & 9 & $-0.330(-0.902)$ & $\begin{array}{l}0.719(0.263-1.966) \\
0.520\end{array}$ & $\begin{array}{l}0.406(0.119-1.386) \\
0.150\end{array}$ \\
\hline Merchants & 27 & 13 & & 1 & 1 \\
\hline \multicolumn{6}{|c|}{ Willingness to pay CBHI } \\
\hline Yes & 235 & 21 & $-2.207(-2.330)$ & $\begin{array}{l}0.110(0.047- \\
0.259) 0.000\end{array}$ & $\begin{array}{l}0.097(0.035-0.267) \\
0.000\end{array}$ \\
\hline
\end{tabular}

Filed survey, 2020/21 


\begin{tabular}{|c|c|c|c|c|c|}
\hline \multirow[t]{2}{*}{ Variables } & \multicolumn{2}{|c|}{$\begin{array}{l}\text { Willingness } \\
\text { to } \\
\text { Join CBHI }\end{array}$} & \multicolumn{2}{|l|}{ Odds Ratio(OR) } & \multirow[b]{2}{*}{ AOR( $(95 \% \mathrm{Cl})$} \\
\hline & Yes & No & B & $\operatorname{COR}(95 \% \mathrm{Cl})$ & \\
\hline No & 16 & 13 & & 1 & 1 \\
\hline \multicolumn{6}{|c|}{$\mathrm{CBHI}$ premium is affordable } \\
\hline Yes & 185 & 15 & $-1.267(-0.544)$ & $\begin{array}{l}0.282(0.135- \\
0.586) 0.001\end{array}$ & $\begin{array}{l}0.580(0.246- \\
1.368) 0.213\end{array}$ \\
\hline No & 66 & 19 & & 1 & 1 \\
\hline \multicolumn{6}{|c|}{ Join in $\mathrm{CBHI}$ have advantage } \\
\hline Yes & 244 & 22 & $-2.945(-2.525)$ & $\begin{array}{l}0.053(0.019- \\
0.147) 0.000\end{array}$ & $\begin{array}{l}0.080(0.027- \\
0.236) 0.000\end{array}$ \\
\hline No & 7 & 12 & & 1 & 1 \\
\hline \multicolumn{6}{|c|}{$\mathrm{CBHI}$ package fulfil the needs of $\mathrm{HH}$ treatment } \\
\hline Yes & 118 & 5 & $-1.638(-1.133)$ & $\begin{array}{l}0.194(0.073-0.518) \\
0.001\end{array}$ & $\begin{array}{l}0.322(0.111- \\
0.936) 0.037\end{array}$ \\
\hline No & 133 & 29 & & 1 & 1 \\
\hline \multicolumn{5}{|c|}{ CBHI health facilities provided a good service } & / \\
\hline Yes & 193 & 14 & $-1.559(-1.313)$ & $\begin{array}{l}0.210(0.100-0.442) \\
0.000\end{array}$ & $\begin{array}{l}0.269(0.118- \\
0.613) 0.002\end{array}$ \\
\hline No & 58 & 20 & & 1 & 1 \\
\hline \multicolumn{6}{|c|}{ Filed survey, 2020/21 } \\
\hline
\end{tabular}

\section{Discussions}

This study revealed that $90.9 \%$ of households were WTJ for proposed community based health insurance. The current finding is in line with the study was conducted in the capital city of Nigeria (96\%) [16] and north of Nigeria (90\%) [17]. the result of this study exceeds those study done in Debub Bench (77.8\%), [18] and, Fogera districts (80\%) [19]. this might be due to variation in the sample size, study period, knowledge, and perception of participants towards the $\mathrm{CBHI}$ scheme.

In this study, the place of residence of the study subjects affects join in CBHI scheme. Urban residence of household heads were 1.484 times less likely to join the scheme compared to rural residences (AOR=1.484; 95\% Cl; 2.343-6.427). This might be in rural area households have large number family size, limited resource and low financial potential, due to this the probability of WTJ the CBHI scheme in rural higher than compared to urban. 
This study also showed the occupational status of $\mathrm{CBHI}$ members had a significant association with join $\mathrm{CBHI}$. Merchants were 0.098 times less likely to join $\mathrm{CBHI}$ than compared to farmers ( $\mathrm{AOR}=0.098 ; 95 \% \mathrm{Cl}$; 0.027-0.363). The study results which is supported by the study conducted in the Edo state of Nigeria [20].This might due to the fact that households heads by merchants were more likely to have the financial ability to cover their health care costs compared to farmer. Farther more, merchants were 0.050 times less likely join in the scheme compared to government employee(AOR=0.050;955 Cl;004-0.639). This night be, due to the fact that household's heads by merchants were more obtained daily income or revenue and easily cover financial cost of health care services than government employee. Because the government employee only have monthly salary and the salary might not enough to cover the health costs.

Household heads willingness to pay $\mathrm{CBHI}$ had significantly associated with willingness to join in the scheme. The respondents were not willingness to pay community based health insurance schemes 0.097 times less likely to join in $\mathrm{CBH}$ than compared to those who pay( $\mathrm{AOR}=0.097 ; 95 \% \mathrm{Cl}=0.035-0.267)$. This might be availability of services in health facility good. Moreover, after joining the scheme is to get high quality health service at affordable costs, quality of health care at public facilities such as patient reception may high. Due to this, pay to $\mathrm{CBHI}$ significantly affect join in $\mathrm{CBHI}$

The study indicated that households join in $\mathrm{CBH}$ scheme were not have advantage 0.080 times less likely to join in the scheme than compared to (Yes) those who have advantages (AOR,0.080; 95\% Cl, 0.0270.236).In the study, community based health insurance package fulfil the needs of $\mathrm{HH}$ treatment indicated a strong positive effect in join the scheme. Household heads who were not CBHI packages fulfil the needs of $\mathrm{HH}$ treatment 0.322 times less likely to join $\mathrm{CBHI}$ than compared to (Yes) the packages fulfil the needs of $\mathrm{HH}$ treatment $(\mathrm{AOR},=0.322 ; 95 \% \mathrm{Cl} ; 0.111-0.936)$.

The study participants shows that $\mathrm{CBHI}$ health facilities provided a good services were significantly associated with willingness to join in $\mathrm{CBHI}$ scheme. Furthermore, the study subjects reported that $\mathrm{CBHI}$ health facilities not provided a good services were 0.269 times less likely to join $\mathrm{CBH}$ than compared to (Yes) $\mathrm{CBHI}$ health facility provided a good services (AOR=0.269; 95\%Cl; $0.118-0.613$ ).the study was similar with other studies results $[8,21]$.This might be due to the direct benefits gained from the quality of services delivered by health institutions.

\section{Conclusions}

According to this study, a high proportion of households were willing to join the $\mathrm{CBHI}$ scheme. A significant number of respondents were got high proportion of health care services from private health center than government health facilities. The main reasons low health care serves utilization in government health institutions were absence of available medicine, lack of enough laboratory equipment, shortage of ambulance services, poor services delivery and health professional's behaviors problems.

\section{Abbreviations}


$\mathrm{CBHl}$; Community based health insurance, AOR; adjusted odds ratio, COR; Crude odds ratio, OOP; out of pocket, ETB; Ethiopian birr, WTJ; willingness to join, $\mathrm{HH}$; household, HF; health facility, SPSS; statistical package for social sciences, $\mathrm{Cl}$; confidence interval

\section{Declarations}

Ethics approval and consent to participate: Ethical clearance was obtained from University of Gondar, College of Social sciences and Humanities Research and Publication condition office (CHSHR\&PCO).A formal letter of cooperation was written to North Mecha Woredas from University of Gondar and permission was obtained from respective kebeles administrators. The study participants were informed about the purpose and their right to refuse the study. After this Oral consent was obtained from all study participants before the interview.

Consent to Publication: Not applicable

Acknowledgment: The authors would like to thank University of Gondar, college of social sciences and humanities the provisions of ethical clearance of support letter. Besides, goes to acknowledge data collectors and supervisors for collecting data accurately. The authors also would like to thank the participants for volunteering participation in the study.

Authors' contributions: Getaneh Bizuayehu Demeke (GBD) prepare the proposal, collect the data, analysis data, interpret data, wrote the results, prepare the manuscript, develop and write up of the full document. All manuscripts prepared by GBD. The author have read and approved the manuscript.

Competing interests: The author declare that they have no competing interests.

Availability of data and materials: All the data supporting the study findings are within the manuscript. Additional detailed information and raw data will be shared upon request addressed to the corresponding author.

Funding: Not applicable

\section{References}

1. Dror D. and, Preker A. Social reinsurance: a new approach to sustainable community health financing. Washington, DC/Geneva: the World Bank/International Labor Organization; 2002.

2. Tabor SR. Community-based health insurance and social protection policy. World Bank, Washington: Social Protection Discussion Paper Series. 2005.

3. Carrin G, Waelkens M-P, Criel B. Community-based health insurance in developing countries: a study of its contribution to the performance of health financing systems. Tropical Med Int Health. 2005 Aug;1(8):799-811. 10(. 
4. Atnafu D, Tilahun H, Alemu Y. Community-based health insurance and healthcare service utilisation, North-West, Ethiopia. BMJ Open. 2018; 8.

5. Adebayo EF, Uthman OA, Wiysonge CS, Stern EA, Lamont KT, Ataguba JE. A systematic review of factors that affect the uptake of community-based health insurance in low-income and middleincome countries. BMC Health Serv Res. 2015;15(1):543. Doi:10.1186/s12913-015-1179-3.

6. World Health Organization. (WHO).Tracking universal health coverage: 2017 global monitoring report.

7. Waelkens M-P, Coppieters Y, Laokri S, Criel B. An in-depth investigation of the causes of persistent low membership of community-based health insurance: a case study of the mutual health organization of Dar Naïm, Mauritania. BMC Health Services Research. 2017;17(535):1-18.

8. Mebratie AD, Sparrow R, Yilma Z, Alemu G, Bedi A. Dropping out of Ethiopia's community-based health insurance scheme. Health Policy and Planning. 2015; 30(10): 1296-1306. Available from: https://doi.org/10.1093/heapol/czu142.

9. Joint NGO. Briefing Paper. Health insurance in low-income countries: Where is the evidence that it works? Oxfam International, Medicine du Monde, Save the Children UK, Plan, Global. Health, Advocates. Act Up Paris. Report number: 112, 2008. Available from.:https://wwwcdn.oxfam.org/s3fspublic/file_attachments/bp112_health_insurance_0805_4.pdf.

10. Dror DM, Hossain SAS, Majumdar A, Perez Koehlmoos TL, John D, Panda PK. What Factors Affect Voluntary Uptake of Community-Based. Health Insurance Schemes in Lowand Middle-Income Countries? A Systematic Review and Meta-Analysis. PLoS ONE. 2016;11(8):1-36.

11. Asfaw A: Innovations in Health Care Financing: New Evidence on the Prospect of Community Health Insurance Schemes in the Rural Areas of Ethiopia. International Journal of Health Care Finance and Economics 2005, 5:241-253. https://doi.org/10.1007/s10754-005-2333-y PMID: 16082517.

12. USAID. Ethiopia's Community-based Health Insurance: A Step on the Road to Universal Health Coverage. 2015.

13. Dibaba A, Hadis M, Ababor S, Assefa Y. Improving Health Care Financing in Ethiopia (SUREpolicy brief).Addis Ababa, Ethiopia: Ethiopian Public Health Institute;2014.

Availablefrom:https://www.who.int/evidence/sure/pdimprovinghealthcarefinancingethiopia.pdf.

14. Federal Ministry of Health Ethiopia. Planning and department. Addis Ababa: Health Insurance Strategy; 2008.

15. Dougals A, Lind, William G, Marchal, Samuel A. Basic statistics for business and economics. 5th ed,. New York: Mc Graw Hall International Campanies; 2006.

16. Adedeji A, Doyin A, Kayode O, Ayodele A. Knowledge, practice and willingness to participate in community health insurance scheme among households in Nigerian capital city. J Med Sci. 2017;12(1):9-18.

17. Gobir AA, Adeyemi AO, Abubaker AA, Audu O, Joshua A. Determinants of willingness to join community-based health insurance scheme in a rural community of north western Nigeria. AJHE. 2016;5:1-10. 
18. Melaku, Haile. Shimeles Ololo and Berhane Megersa; Willingness to join community-based health insurance among rural households of Debub Bench District, Bench Maji Zone, Southwest Ethiopia. BMC Public Health. 2014;14(591):1-10.

19. Adane Kebede M, Gebreslassie, Yitayal M. Willingness to Pay for Community Based Health Insurance among Households in the Rural Community of Fogera District, North West Ethiopia. International Journal of Economics Finance Management Sciences. 2014;2(4):263-9.

20. Oriakhi HO, Onemolease EA. Determinants of rural household's willingness to participate in community based health insurance scheme in Edo State, Nigeria. Ethno-Medicine. 2012;6(2):95-102.

21. Nair D. Determinants of Enrollment in Comprehensive Health Insurance Scheme and Implementation Challenges: A Study in Kerala, South India. Health Sci J. 2015;10(1):8. 